\title{
Altruistic (Costly) Punishment as Motivation for Vindictive Rape
}

\author{
R. Karl Hanson ${ }^{a}$
}

[a] Department of Psychology, Carleton University, Ottawa, Canada.

Sexual Offending: Theory, Research, and Prevention, 2020, Vol. 15(1), Article e3067, https://doi.org/10.5964/sotrap.3067

Received: 2019-12-27 • Accepted: 2020-03-18 • Published (VoR): 2020-07-22

Handling Editor: Martin Rettenberger, Centre for Criminology (Kriminologische Zentralstelle - KrimZ), Wiesbaden, Germany

Corresponding Author: R. Karl Hanson, Department of Psychology, Carleton University, 1125 Colonel By Drive, Ottawa, Ontario, K1S 5B6, Canada. Phone: +1 (613) 619-0817. E-mail: rkarlhanson@gmail.com

\begin{abstract}
This paper presents a model of vindictive rape based on common mechanisms for maintaining cooperation among humans, namely altruistic (or costly) punishment, sex role expectations, and retributive ("eye for an eye") justice. Vindictive rapes are characterized by high level of victim harm without explicit sadistic sexual interests. They are also distinguished from angry, reactive sexual aggression in response to personal insult or threats. In this model, vindictive rape is considered a form of retributive justice in which the perpetrator punishes the female victim for perceived transgressions against sexual norms. None of the specific psychological mechanisms are intrinsically problematic. Nevertheless, individuals who have committed vindictive rapes would still be expected to have risk-relevant schema worthy of interventions. For such individuals, the primary treatment targets would be loosening rigid sexual norm expectations for women, increasing confidence in conventional methods of maintaining social order, and decreasing willingness to hurt others at the cost of hurting oneself. A 15-item Vindictive Rape Attitude Questionnaire is presented in order to facilitate further research on the topic.
\end{abstract}

\section{Keywords}

altruistic punishment, vindictive rape, sexual offending, attitudes, empathy 


\section{Highlights}

- The mechanisms responsible for human cooperation can also explain serious social transgressions.

- Some rapes may be intended to punish women for perceived violations of sexual norms.

- To promote future research, a new 15-item Vindictive Rape Attitude Questionnaire is presented.

The goal of this article is to provide a theoretical model for certain types of sexual offending rooted in contemporary scientific debates about human nature (B. Hare, 2017; Henrich, 2017; Pinker, 2012; Young, 2012a). The basic model assumes Darwinian co-evolution of biology and culture. Our brains are the way they are because of our experience with other people. How we interact with each other is grounded in our brain structures. Psychologically, these structures are experienced as schema that shape our understanding of the world and potentiate action. Although there are many culturally specific beliefs and practices, this paper focused on schema that are widely shared across culture. Viewing sexual offending from the broad perspective of co-evolution provides new opportunities for research. It also has the potential of suggesting new approaches to the assessment and treatment of individuals with a history of sexual offending.

Cooperation is a puzzle for the social sciences. According to certain popular versions of evolutionary theory, such as the one promoted in the first (1976) edition of Dawkins' The selfish gene, our very existence depends on our selfishness. If our genes did not somehow triumph over other genes, we simply would not be here. How then, do we explain cooperation among unrelated humans? The evidence for cooperation is everywhere: we give directions to strangers, we have free markets for goods and services, and we review manuscripts for open-access, international scientific journals. It is uncontroversial that cooperation contributes to the success of our business, our science, and our species (Henrich, 2017).

The mechanisms supporting cooperation are not fully understood, and remain an important focus a topic of debate in the scientific community (e.g., Bhui et al., 2019; Fowler, 2005; Henrich \& Henrich, 2006). The focus of this article, however, is not cooperation; instead, the focus is on failures of cooperation, i.e., cheating, free-loading, rule breaking, interpersonal violence - in other words: criminal behaviour. The basic thesis is that rule violation can be explained by the same mechanisms that are responsible for social cooperation. In particular, this paper presents a model of vindictive rape rooted in the constructs of altruistic punishment, empathy cruelty, and retributive (eye for an eye) justice. 


\section{Vindictive Rape Is Not Well Understood}

Vindictive rape is characterized by high levels of overt violence and relative low levels of sexual interest in sadistic acts (Barbaree et al., 1994; Knight, 2010b). Individuals who have committed vindictive rapes do not justify their acts by recourse to uncontrolled sexual urges; instead, they appeal to features of their victims that make them worthy of punishment. Using the MTC:R3 classification system (Knight, 2010b; Knight \& Prentky, 1990), Barbaree et al. (1994) classified 14 out of 60 (23.3\%) individuals with a history of rape are primarily vindictive. In comparison, 8 out of 60 (13.3\%) were classified as sadistic.

Research on (non-vindictive) rape has largely been guided by constructs related to negative attitudes towards women and general antisociality (Knight \& Sims-Knight, 2003; Malamuth, 2003). Using only enough force to obtain sexual compliance does not present strong theoretical challenges. Men who want sex may force themselves on women when they have little regard for the sexual rights of women, and, in contemporary society, are also willing to break the law. From a sociobiological perspective, rape can lead to reproductive success (Lalumière et al., 2005). The historical record is full of examples of invaders building empires by killing the males of the opposing group and consigning their women to sexual slavery. Inflicting more harm than necessary to obtain sexual compliances, however, does not advance reproductive success. Other explanations are required.

Sexual sadism is perhaps the dominant explanation for excessively violent sexual crimes. In general, sadism is characterized by "a sustained, focused and intense pattern of sexual arousal ...that involves the infliction of physical or psychological suffering on a non-consenting person" (World Health Organization, 2019). Important clinical features of this disorder are sexually arousing sadistic thoughts and fantasies. Vindictive rape, however, is considered to have primarily nonsexual motives.

Excessive sexual violence, particularly sexual murders, has been explained by both sadism and pervasive, intense anger toward women (Beauregard et al., 2007). Although the anger-motivated sexual murders shared many features with sadistic murders, individuals who committed anger-motivated sexual murders were less likely to have planned the offence, less likely to humiliate or mutilate the victim, and more likely to select a victim previously known to them. Compared to the sadistic murders, they were also more likely to turn themselves into the police and fully admit to their offences. Often, the anger-motivated murders were linked to situational triggers, such as humiliation and rejection of the offender (Cusson \& Proulx, 2007). Vindictive rape could be considered a subset of the general category of anger-motivated sexual aggression. Vindictive rape, however, may have distinctive features; in particular, it may not require the personal affront commonly associated with anger-motivated sexual aggression.

There has been little research interest in vindictive rape in recent years. One of the contributing factors is the difficulty of ruling out sexual motivation. The assessment 
of certain clinical features, such as a history of sadistic fantasies, depend heavily on self-report. Given concerns about low diagnostic reliability, Marshall and Hucker (2006) recommended that sadism be assessed based on offence history, a recommendation that has been followed by current assessment measures of sexual sadism. The SeSaS, for example, contains items that primarily describe offence behaviours (Mokros et al., 2012, 2014). Consequently, an individual who degrades, humiliates, and physically harms a woman in a sexualized context is likely to be considered sadistic, regardless of how the individual explained his behaviour (Eher et al., 2016).

Another reason for decreased interest in vindictive rape is that the developer of the MTC:R3 classification system, Raymond Knight, no longer believes that vindictive rate is a distinct class. Knight now considers vindictiveness to be as feature of what he calls the agonistic continuum (Knight, 2010a). The agonistic continuum is a dimension reflecting the extent to which individuals are sexually motivated to engage in acts that physically hurt, humiliate, or degrade others (Longpré et al., 2018).

It is also possible that research and clinical attention to vindictive rape has faded for lack of a compelling theoretical model. All complex human behaviour is influenced by multiple factors, and it is hard to separate out the contributions of separate elements. Our simplifications of reality (our models), nevertheless, guide our research and clinical activities. If the arguments presented in the paper are correct, then we may be failing to adequately address certain rape-related risk factors important.

In contrast to the ongoing work on sexual sadism, there has been little attention to nonsexual motivations for inflicting sexual harm. In our 2013 review of attitudes as risk factors for sexual recidivism, we found that attitudes were less predictive for individuals who had offended against adults compared to individuals who had sexually offended against children (Helmus et al., 2013, p. 41). This led us to consider whether our implicit psychological models for child molesting were better than were our implicit models for explaining rape. Within corrections and forensic mental health, sexual offending is often explained by general criminality (e.g., negative attitudes toward authority, psychopathy) and sex crime specific criminality (e.g., deviant sexual interests, emotional identification with children; Brouillette-Alarie et al., 2016; Hanson \& Morton-Bourgon, 2005; Quinsey, 1986; Seto, 2019). Most of the rape attitude measures in Helmus et al.'s (2013) reviewed focused on minimization of harm and disregard for the sexual rights of women. There appeared to be an opportunity to extent our theoretical reach to better identify what motivates men to sexually hurt women.

\section{The Mechanisms of Human Cooperation}

The psychological mechanisms that bind humans together are intuitive heuristics that rapidly define the meaning of social interactions and prime our emotional and behavioural responses (schema). By intuitive heuristics, I am referring to System 1 thinking in 
Kahneman's (2011) model. System 2 thinking requires effort and planful analysis (e.g., researching which car to buy). System 1 thinking is rapid, appearing automatic and effortless (e.g., swerving to avoid a careless pedestrian). Although System 1 thinking can be learned (e.g., playing tennis), we are born primed to develop many schema, particularly schema involving our relationships with each other (e.g., feeling shame, recognizing anger in others, having tender feelings for intimates). These social schemata are potentially accessible to all people in all cultures; nevertheless, the extent to which they are developed and expressed vary across individuals and settings.

One of these mechanisms is empathy, defined as the ability to appreciate the thoughts, feelings, and perspective of others. It is hard to cooperate without input and feedback from the other team members. We also assume that others will not continue in harmful actions when victim suffering is salient. This model has had considerable influence on treatment programs for sexual offenders (Mann \& Barnett, 2013). Increasing victim empathy was a goal of the earliest structured treatment programs (Hildebran \& Pithers, 1989), and was still a key component of $85 \%$ of Canadian and US programs surveyed by McGrath and colleagues (2010) in 2009. Many programs continued to focus on increasing the salience of victim suffering despite strong evidence that awareness of victim suffering was unrelated to sexual recidivism (Hanson \& Morton-Bourgon, 2004, 2005; Mann et al., 2010). Furthermore, programs that focus on factors victim empathy tend to be ineffective (Hanson et al., 2009).

The persistent concern about low victim empathy among offenders suggests System 1 thinking. Therapists are not reviewing the research literature to identify empirically validated dynamic risk factors. Instead, the therapists, like the rest of us, have immediate, negative reactions upon hearing individuals responsible for serious sexual transgressions justify their actions by blaming their victims. The perpetrators are expressing a type of empathy deficit, but one that is quite different from the empathy deficit of failing to appreciate that the victim suffered. To better understand empathy's role in vindictive rape, we need to distinguish between empathy kindness or sympathy, and empathic cruelty.

\section{Empathic Kindness}

The term empathy is a recent addition to Western languages (Hanson, 2003, 2011; Jahoda, 2005). Early in the $20^{\text {th }}$ Century, it was used by German psychologists (Einfühlung) to describe our capacity to give meaning to abstract objects (e.g., that tall, straight building feels imposing and unfriendly). Subsequently, the term was adopted and translated by American psychologists to describe how we share the experiences of others. Carl Rogers, in particular, did much to promote the concept of empathy when he identified "accurate empathy” as a core characteristic of effective psychotherapists (e.g., Rogers, 1957). An 
empirical link between empathy and diverse prosocial behaviours has been recognized for many years (Eisenberg \& Miller, 1987; Roberts \& Strayer, 1996).

Given the association between empathy and prosocial behaviour, it is natural to expect that individuals who engage in antisocial behaviour would have empathy deficits. The empirical results, however, have been equivocal. There is a clear link between antisocial behaviour and callous-unemotional traits (e.g., the Affective factor in the 4-factor division of PCL-R items; R. Hare \& Neumann, 2006); however, the assessment of callous-unemotional traits is largely influenced by behavioural history. The research has not demonstrated a clear link about antisocial behaviour and deficits in the ability to appreciate the thoughts and feelings of others. In an early major review, Jolliffe and Farrington (2004) found a positive association between empathy deficits and violent crime; however, the association disappeared after controlling for intelligence and social-economic status. A more recent meta-analysis by Vachon et al. (2014) found a positive, but small, relationship between low empathy and diverse types of aggression.

Empathy may inhibit aggression in some circumstances, but it can also increase aggression. To quote the $18^{\text {th }}$ century philosopher Adam Smith, "[w]hen we see one man oppressed or injured by another, the sympathy which we feel with the distress of the sufferer seems to serve only to animate our fellow-feeling with his resentment against the offender. We are rejoiced to see him attack his adversary in his turn, and are eager and ready to assist him" (quoted in Bloom, 2017). A current example of the same mechanism is the widespread public hostility towards individuals who have committed sexual offences.

A central feature of violent crimes is the intention to hurt others. Harming others without intent is negligence. Harming with intent is assault. It is hard to imagine that the perpetrators of vindictive rapes or domestic assaults did not recognize that their victims suffer. Forcing sexual acts at gunpoint or beating your unfaithful spouse with a baseball bat cannot be explained by a failure to recognize distress signals.

\section{Altruistic Punishment}

There is, however, another type of empathy deficit that could explain active intentions to hurt others: altruistic punishment, or our innate desire to punish people who have done bad things (Fehr \& Gächter, 2002; Henrich et al., 2006). What distinguishes altruistic punishment from simple vengeance or retribution is that the person being punished has not transgressed against us personally. Instead, they have harmed somebody else, or violated social norms. It is altruistic, or costly, in that the perpetrator commit resources to correcting an injustice committed against an unrelated stranger. During the last 15 years, social science researchers have explored the role of altruistic punishment in facilitating human cooperation. Although debate continues, relatively simple assumptions can be used to create evolutionary models in which gene pools containing individuals prone to 
altruistic punishment come to dominate over groups lacking this inclination (e.g., Fowler, 2005).

So what has altruistic punishment to do with empathy? Empathy is an extremely valuable skill for detecting cheating and defection. In the anthropological record, there is a period of rapid growth of human brain size that coincided with increased social organization (Young, 2012a). One explanation for the growth in brain size is that we need them to deal with each other. Given that it is easy for those with greater cognitive ability to take advantage of those with lesser ability, some anthropologists have referred to this escalation of brain size as a cognitive arms race (Young, 2012a). In this model, empathy, the capacity to rapidly appreciate the mental states of others, is a strategic weapon.

More generally, maintaining cooperation within small groups requires accurate readings of the intentions of others. And it requires that cheaters are rapidly detected, and punished. Consequently, altruistic punishment is linked to empathic cruelty (Young, 2012a, 2012b). We experience the urge to punish as anger (Seip et al., 2009). We see an injustice; we feel angry; we strike out. As an automatic, intuitive process, our reactions are not filtered through careful reflection and may, consequently, go against our own best interests.

Under this model, there is no intrinsic link between empathy deficits and antisocial behaviour. In fact, individuals with psychopathic traits have better than average skills at identifying individuals vulnerable to victimization (Book et al., 2013; Wheeler et al., 2009). Angela Book and colleagues, for example, found that individuals high on psychopathy could identify individuals vulnerable to victimization simply by watching them walk down a corridor (Wheeler et al., 2009). Similarly, successful child molesters must have excellent skills at identifying vulnerable children who would accept gifts and adult attention in exchange for sexual favours.

The desire to inflict altruistic punishment is typically assessed using economic game exercises, in which participants have the option of spending their own credits for no benefit other than seeing a wrong-doer lose their credits. Although the tendency towards altruistic punishment is evident in all cultures, there is substantial cultural and individual variation (Henrich et al., 2006). It is, however, an immediate, intuitive reaction. Rates of altruistic punishment increase with increased impulsivity, and both impulsivity and altruistic punishment increase with decreased serotonin (Crockett et al., 2010). The emotional satisfaction of altruistic punishment is associated with activation of the dorsal striatum (de Quervain et al., 2004).

Interestingly, individuals with psychopathic traits are among those most motivated to inflict altruistic punishment (Masui et al., 2011). The connection may be attributed to a commonly link with impulsive decision making. However, from a broader theoretical perspective, it could also be that these individuals have a deficit in a core mechanism for social cooperation. They punish transgressions with more frequency and with more force than is conducive to social harmony. 
At this point, I have developed an image of the violent offender as bad cop. The violent offender uses violence to punish wrongdoing, but the sanctions are illegitimate because they are disproportional to the transgressions. Western democracies have successfully limited interpersonal violence by restricting the use of force to authorized agents of the state (e.g., armies, police, corrections; Pinker, 2012). Unrestrained application of physical punishment is a serious threat to the dominant social order; however, physically punishing cheats and defectors may be perceived as a reasonable option for individuals without access to mainstream justice systems (e.g., immigrant drug dealers; victims of serious non-criminal transgressions, such as personal betrayal and infidelity).

There is one more concept needed before applying this model to vindictive rape. In all cultures, there is the expectation that those who break the rules (or cheat) will be punished. There is also an expectation that the punishment will suit the crime. Those who steal food will go hungry. Those with excess pride will be humiliated. This theme of retributive justice has been present since the first legal codes ("eye for an eye" was in the Code of Hammurabi, c. 1754 B.C.) and continues to this day with the popular impulse to punish sexual offending by castration.

Now consider a psychological "bad cop" with negative attitudes toward women. In his view, there are specific things that women should and should not do. Women who violate standards deserve to be punished. To make the punishment fit the crime, women who transgress gender roles or sexual norms should be punished sexually. This model does not require any specific paraphilic interest in violence. Rather than pathological sadism, the motivation to sexually punish women is a variation of our near-universal desire to punish wrong-doers.

If this model is correct, the vindictive rapist's major psychological problems would not be an inability to appreciate women's thoughts and feelings. In fact, these rapists would be expected to be acutely sensitive to women's moods and intentions as they concern sexuality and gender role conformity. Just as individuals high on psychopathy are adept at identifying victims to rob, individuals prone to rape may be skilled at detecting when women are flaunting their sexuality or engaging in forbidden sexual activities.

When I was beginning my work in the area of sexual violence in the 1980's, there was considerable discussion of Against our will, a 1975 book by Susan Brownmiller. Brownmiller argued that rape was not motivated by deviant sexual interests, nor by psychological deficits of the perpetrators. Instead, rape was a "conscious process of intimidation by which all men keep all women in a state of fear." Her proclamation was advocacy, not scientific discourse. She did, however, capture a sentiment shared by many women. In terms of the model developed in this paper, she was giving voice to what it feels like to be on the receiving end of altruistic punishment. Brownmiller recognized that rape can be a form of social control of men over women, a sentiment shared by certain men motivated to commit vindictive rapes. 


\section{Attitudes Supportive of Vindictive Rape}

The above model of vindictive rape was intended to improve the assessment of problematic attitudes of men who sexually assault women. Previous rape attitude research had focused on a) justification and minimizations (e.g., it was not that bad, she really wanted it), b) hostility towards women (e.g., women are not worthy of respect), and c) generalized antisociality (e.g., I take what I want when I want it). Although empathic cruelty is expected to share features of generalized cruelty and cruelty towards women, in particular, there is a key distinction. Altruistic punishment would not be directed towards the class of women as a whole; instead, it would focus on certain women doing specific types of acts that are perceived as transgressions of sexual decency.

The next question was whether such attitudes are actually present in men who have committed rape. This required a new measure. Consequently, I put together a 15-item Vindictive Rape Attitude Questionnaire (VRAQ, see Appendix). The items were selected to represent the belief that women who transgress sexual norms are exempt from protection and are worthy of punishments. So far, it has only been used as a secondary measure in studies focusing on other issues.

D'Urso and colleagues (2019) administered an Italian translation of the VRAQ to 120 men serving a sentence for sexual offence in Italian prisons. The internal consistency was acceptable (Cronbach's alpha $=.78$ ). Vindictive attitudes showed moderate, positive correlations with general moral disengagement $(r=.30)$, attribution of blame $(r=.37)$, displacement of responsibility $(r=.26)$ and diffusion of responsibility $(r=.24)$ as measured by the Moral Disengagement Scale (MDS; Caprara et al., 1996). The MDS operationalizes Bandura's $(1986,1999)$ list of cognitive strategies used to break free from the ethical codes imposed by society. VRAQ scores were negatively correlated with education $(r=-.30)$, such that individuals with low educational attainment were more likely to endorse more vindictive attitudes towards women. The positive correlations with moral disengagement raise questions concerning the extent to which vindictive attitudes precede and motivate offending. They may function as post hoc justifications for acts that they did for other reasons (e.g., reactive aggression, sadism). The association between vindictive attitudes and the degree of violence in the sexual offences was not examined in this study.

Longpré et al. (2018) used the VRAQ in a questionnaire study of the construct validity of the agonistic continuum. The respondents were either university students $(n=48)$ or adults solicited from MTurk ( $n=354$, total sample of 402$)$. The agonistic continuum was assessed by 30 self-report items concerning hurting others (e.g., I hurt people for my own enjoyment, I have beaten someone while I was having sex). Notice that the sexual and nonsexual harm items were part of the same construct. They found that vindictive attitudes (VRAQ total scores) showed a moderate correlation $(r=.33)$ with the total scores on their agonistic continuum questionnaire. Other correlates included meanness, narcissism, psychopathy, and general antisociality. 


\section{Implications for Treatment}

Effective interventions for individuals who have committed rape requires understanding the factors that contribute to their offending behaviour. The contributing factors are expected to be diverse and interconnected, and numerous factors have been document in previous research (e.g., hostility toward women, psychopathy, reactive aggression, sadism). If the model presented in the current paper is correct, there is still room for treatment providers to expand their range of potential treatment targets for individuals who commit vindictive rape. Specifically, vindictive rape may be a form of retributive justice in which the perpetrator is punishing the female victim for perceived transgressions against sexual norms.

For such individuals, focusing on victim empathy and the harm caused by sexual assault would be expected to have little influence on their recidivism potential. Instead, treatment is more likely to be effective when it focuses on a) rigid sexual norm expectations for women, b) distrust of conventional methods of social control, and c) a willingness to act upon immediate experiences of anger. More generally, this model suggest that interventions aimed at treating the risk for violence should soften offenders' judgements concerning conduct worthy of punishment, highlight the problems with taking the law into one's own hand, build patience, and encourage the use of cooperative methods of conflict resolution and social control.

\section{Implications for Research}

The intent of this paper was to open up new ways of understanding the intent to harm others sexually, and to stimulate research that improves the assessment of problematic attitudes of men who commit rape. The initial research on the Vindictive Rape Attitude Scale (VRAQ) appeared promising, but much more is needed before we can tell whether it adds to what we already know about the attitudes of individuals who commit rape (Anderson et al., 1997; Johnson \& Beech, 2017; Polaschek \& Ward, 2002).

In particular, there are certain hypotheses from the model that are worth testing. For example, this model suggests that individuals who commit vindictive rape are more ready to inflict altruistic punishment compare to individuals who have committed other forms of sexual assault, or none at all. This could be tested in both community and correctional samples using the HSAQ, Longpré et al.'s (2018) agonistic continuum scale, and a standard version of the altruistic punishment game (Crockett et al., 2010; Henrich et al., 2006; Masui et al., 2011).

Another interesting hypothesis is that vindictive rapists may be better than other groups at identifying women who violate social norms concerning sexuality. Just as individuals high on psychopathy are good at identifying crime victims (Wheeler et al., 2009), individuals prone to vindictive rape may be particularly good at identifying wom- 
en's sexual behaviour history based on their appearance (photographs) or brief social interactions.

Research is also needed on the extent to which the sexual punishments are actually altruistic. Even if it was possible to rule out sadistic motivations, individuals may still have strong personal grievances against their victims. These grievances and affronts are frequently connected to perceived personal insults and rejection. For punishment to be altruistic, the transgressions being punished should be against valued sexual norms. It is likely that there is wide cultural variation in the frequency with which such crimes attract the attention of the criminal justice system. If the women's transgressions are locally perceived as serious, then inflicting punishment on these women may not be considered an egregious crime.

In terms of the Risk/Need/Responsivity model of offender rehabilitation (Andrews et al., 1990), an important next step would be to consider whether the attitudes associated with this model predict sexual, violent, and general recidivism. In particular, do they add new information not addressed by the constructs already routinely assessed, such as negative attitudes towards women, reactive anger, and antisocial orientation? Prospective studies would be preferred; however, it may be possible to create coding guidelines that assess the core features of these attitudes from detailed clinical files.

\section{Conclusion}

In summary, looking at the psychological mechanisms responsible for human cooperation could inform our understanding of criminal behavior. These mechanisms are intuitive heuristics that rapidly define the meaning of social interactions and prime our emotional and behavioural responses. I have discussed several of these mechanisms, including empathic kindness and empathic cruelty (altruistic punishment). Individuals lacking in empathy kindness will be negligent, failing to stop when their actions accidentally harm others. In contrast, individuals with an excess of empathic cruelty will actively and intentionally inflict pain and suffering on others. Although it does not take a forensic psychologist to know that some people wish harm on others, there is a non-obvious implication of this model: namely, that the basic psychological motivations of vindictive rapists may run on the same fuel as that which created the state institutions responsible for enforcing the law that punishes them. 
Funding: The author has no funding to report.

Competing Interests: The author has declared that no competing interests exist.

Previously Presented: An earlier version of this paper was presented at the Winterschool Research in Forensic Psychology conference, Seeon, Germany, February 2, 2013.

Acknowledgments: The author has no support to report.

\section{References}

Anderson, K. B., Cooper, H., \& Okamura, L. (1997). Individual differences and attitudes toward rape: A meta-analytic review. Personality and Social Psychology Bulletin, 23(3), 295-315. https://doi.org/10.1177/0146167297233008

Andrews, D. A., Bonta, J., \& Hoge, R. D. (1990). Classification for effective rehabilitation: Rediscovering psychology. Criminal fustice and Behavior, 17(1), 19-52. https://doi.org/10.1177/0093854890017001004

Bandura, A. (1986). The explanatory and predictive scope of self-efficacy theory. Fournal of Social and Clinical Psychology, 4(3), 359-373. https://doi.org/10.1521/jscp.1986.4.3.359

Bandura, A. (1999). Moral disengagement in the perpetration of inhumanities. Personality and Social Psychology Review, 3(3), 193-209. https://doi.org/10.1207/s15327957pspr0303_3

Barbaree, H. E., Seto, M. C., Serin, R. C., Amos, N. L., \& Preston, D. L. (1994). Comparisons between sexual and nonsexual rapist subtypes: Sexual arousal to rape, offense precursors, and offense characteristics. Criminal fustice and Behavior, 21(1), 95-114. https://doi.org/10.1177/0093854894021001007

Beauregard, E., Proulx, J., \& St-Yves, M. (2007). Angry or sadistic: Two types of sexual murderers. In J. Proulx, E. Beauregard, M. Cusson, \& A. Nicole (Eds.), Sexual murderers: A comparative analysis and new perspectives (pp. 123-142). Hoboken, NJ, USA: John Wiley \& Sons.

Bhui, R., Chudek, M., \& Henrich, J. (2019). How exploitation launched human cooperation. Behavioral Ecology and Sociobiology, 73(6), Article 78. https://doi.org/10.1007/s00265-019-2667-y

Bloom, P. (2017). Empathy and its discontents. Trends in Cognitive Sciences, 21(1), 24-31. https://doi.org/10.1016/j.tics.2016.11.004

Book, A., Costello, K., \& Camilleri, J. A. (2013). Psychopathy and victim selection: The use of gait as a cue to vulnerability. fournal of Interpersonal Violence, 28(11), 2368-2383. https://doi.org/10.1177/0886260512475315

Brouillette-Alarie, S., Babchishin, K. M., Hanson, R. K., \& Helmus, L. (2016). Latent constructs of static risk scales for the prediction of sexual aggression: A 3-factor solution. Assessment, 23(1), 96-111. https://doi.org/10.1177/1073191114568114 
Brownmiller, S. (1975). Against our will: Men, women and rape. New York, NY, USA: Simon \& Schuster.

Caprara, G. V., Barbaranelli, C., Vicino, S., \& Bandura, A. (1996). La misura del disimpegno morale [Measurement of moral disengagement]. Rassegna di Psicologia, 13, 93-105.

Crockett, M. J., Clark, L., Lieberman, M. D., Tabibnia, G., \& Robbins, T. W. (2010). Impulsive choice and altruistic punishment are correlated and increase in tandem with serotonin depletion. Emotion, 10(6), 855-862. https://doi.org/10.1037/a0019861

Cusson, M., \& Proulx, J. (2007). The motivation and criminal career of sexual murderers. In J. Proulx, E. Beauregard, M. Cusson, \& A. Nicole (Eds.), Sexual murderers: A comparative analysis and new perspectives (pp. 143-173). Hoboken, NJ, USA: John Wiley \& Sons.

Dawkins, R. (1976). The selfish gene. Oxford, United Kingdom: Oxford University Press.

de Quervain, D. J.-F., Fischbacher, U., Treyer, V., Schellhammer, M., Schnyder, U., Buck, A., \& Fehr, E. (2004). The neural basis of altruistic punishment. Science, 305(5688), 1254-1258. https://doi.org/10.1126/science.1100735

D’Urso, G., Petruccelli, I., Grilli, S., \& Pace, U. (2019). Risk factors related to cognitive distortions toward women and moral disengagement: A study on sex offenders. Sexuality \& Culture, 23(2), 544-557. https://doi.org/10.1007/s12119-018-9572-9

Eher, R., Schilling, F., Hansmann, B., Pumberger, T., Nitschke, J., Habermeyer, E., \& Mokros, A. (2016). Sadism and violent reoffending in sexual offenders. Sexual Abuse, 28(1), 46-72. https://doi.org/10.1177/1079063214566715

Eisenberg, N., \& Miller, P. A. (1987). The relation of empathy to prosocial and related behaviors. Psychological Bulletin, 101(1), 91-119. https://doi.org/10.1037/0033-2909.101.1.91

Fehr, E., \& Gächter, S. (2002). Altruistic punishment in humans. Nature, 415(6868), 137-140. https://doi.org/10.1038/415137a

Fowler, J. H. (2005). Altruistic punishment and the origin of cooperation. Proceedings of the National Academy of Sciences of the United States of America, 102(19), 7047-7049. https://doi.org/10.1073/pnas.0500938102

Hanson, R. K. (2003). Empathy deficits of sexual offenders: A conceptual model. Fournal of Sexual Aggression, 9(1), 13-23. https://doi.org/10.1080/1355260031000137931

Hanson, R. K. (2011). Invoking sympathy: The assessment and treatment of empathy deficits among sexual offenders. In B. K. Schwartz (Eds.), Handbook of sex offender treatment (pp. 3-1 to 3-12). Kingston, NJ, USA: Civic Research Institute.

Hanson, R. K., Bourgon, G., Helmus, L., \& Hodgson, S. (2009). The principles of effective correctional treatment also apply to sexual offenders: A meta-analysis. Criminal fustice and Behavior, 36(9), 865-891. https://doi.org/10.1177/0093854809338545

Hanson, R. K., \& Morton-Bourgon, K. E. (2004). Predictors of sexual recidivism: An updated metaanalysis (Corrections User Report No. 2004-02: Public Safety and Emergency Preparedness Canada). Retrieved from https://www.publicsafety.gc.ca/cnt/rsrcs/pblctns/2004-02-prdctrs-sxl-rcdvsm-pdtd/indexen.aspx 
Hanson, R. K., \& Morton-Bourgon, K. E. (2005). The characteristics of persistent sexual offenders: A meta-analysis of recidivism studies. fournal of Consulting and Clinical Psychology, 73(6), 1154-1163. https://doi.org/10.1037/0022-006X.73.6.1154

Hare, B. (2017). Survival of the friendliest: Homo sapiens evolved via selection for prosociality. Annual Review of Psychology, 68, 155-186. https://doi.org/10.1146/annurev-psych-010416-044201

Hare, R. D., \& Neumann, C. S. (2006). The PCL-R assessment of psychopathy. In C. J. Patrick (Ed.), Handbook of psychopathy (pp. 58-88). New York, NY, USA: Guilford.

Helmus, L., Hanson, R. K., Babchishin, K. M., \& Mann, R. E. (2013). Attitudes supportive of sex offending predict recidivism: A meta-analysis. Trauma, Violence \& Abuse, 14(1), 34-53. https://doi.org/10.1177/1524838012462244

Henrich, J. (2017). The secret of our success: How culture is driving human evolution, domesticating our species, and making us smarter. Princeton, NJ, USA: Princeton University Press.

Henrich, J., \& Henrich, N. (2006). Culture, evolution and the puzzle of human cooperation. Cognitive Systems Research, 7(2-3), 220-245. https://doi.org/10.1016/j.cogsys.2005.11.010

Henrich, J., McElreath, R., Barr, A., Ensminger, J., Barrett, C., Bolyanatz, A., . . Ziker, J. (2006). Costly punishment across human societies. Science, 312(5781), 1767-1770. https://doi.org/10.1126/science.1127333

Hildebran, D., \& Pithers, W. D. (1989). Enhancing offender empathy for sexual-abuse victims. In D. R. Laws (Ed.), Relapse prevention with sex offenders (pp. 236-243). New York, NY, USA: Guilford. Jahoda, G. (2005). Theodor Lipps and the shift from "sympathy" to "empathy". Journal of the History of the Behavioral Sciences, 41(2), 151-163. https://doi.org/10.1002/jhbs.20080

Johnson, L. G., \& Beech, A. (2017). Rape myth acceptance in convicted rapists: A systematic review of the literature. Aggression and Violent Behavior, 34, 20-34.

https://doi.org/10.1016/j.avb.2017.03.004

Jolliffe, D., \& Farrington, D. P. (2004). Empathy and offending: A systematic review and metaanalysis. Aggression and Violent Behavior, 9(5), 441-476. https://doi.org/10.1016/j.avb.2003.03.001

Kahneman, D. (2011). Thinking, fast and slow. New York, NY, USA: Doubleday/Random House.

Knight, R. A. (2010a). Is a diagnostic category for paraphilic coercive disorder defensible? Archives of Sexual Behavior, 39(2), 419-426. https://doi.org/10.1007/s10508-009-9571-x

Knight, R. A. (2010b). Typologies for rapists: The generation of a new structural model. In A. Schlank (Ed.), The sexual predator (Vol. 4, pp. 17-1 to 17-28). Kingston, NJ, USA: Civic Research Institute.

Knight, R. A., \& Prentky, R. A. (1990). Classifying sexual offenders. In W. L. Marshall, D. R. Laws, \& H. E. Barbaree (Eds.), Handbook of sexual assault (pp. 23-52). Boston, MA, USA: Springer.

Knight, R. A., \& Sims-Knight, J. E. (2003). The developmental antecedents of sexual coercion against women: Testing alternative hypotheses with structural equation modeling. In R. A. Prentky, E. S. Janus, \& M. C. Seto (Eds.), Sexually coercive behavior: Understanding and management [Annals of the New York Academy of Sciences, Volume 989] (pp. 72-85). New York, NY, USA: New York Academy of Sciences. 
Lalumière, M. L., Harris, G. T., Quinsey, V. L., \& Rice, M. E. (2005). The causes of rape: Understanding individual differences in male propensity for sexual aggression. Washington, DC, USA: American Psychological Association.

Longpré, N., Knight, R. A., \& Guay, J.-P. (2018, October 17-20). Unpacking the etiology and potential mechanisms underlying the agonistic continuum. Paper presented at the 37th Annual Research and Treatment Conference of the Association for the Treatment of Sexual Abusers (ATSA), Vancouver, BC, Canada.

Malamuth, N. M. (2003). Criminal and noncriminal sexual aggressors: Integrating psychopathy in a hierarchical-mediational confluence model. In R. A. Prentky, E. S. Janus, \& M. C. Seto (Eds.), Sexually coercive behavior: Understanding and management [Annals of the New York Academy of Sciences, Volume 989] (pp. 33-58). New York, NY, USA: New York Academy of Sciences.

Mann, R. E., \& Barnett, G. D. (2013). Victim empathy intervention with sexual offenders:

Rehabilitation, punishment, or correctional quackery? Sexual Abuse, 25(3), 282-301. https://doi.org/10.1177/1079063212455669

Mann, R. E., Hanson, R. K., \& Thornton, D. (2010). Assessing risk for sexual recidivism: Some proposals on the nature of psychologically meaningful risk factors. Sexual Abuse, 22(2), 191-217. https://doi.org/10.1177/1079063210366039

Marshall, W. L., \& Hucker, S. J. (2006). Issues in the diagnosis of sexual sadism. Sexual Offender Treatment, 1(2). Retrieved from http://www.sexual-offender-treatment.org/40.html

Masui, K., Iriguchi, S., Nomura, M., \& Ura, M. (2011). Amount of altruistic punishment accounts for subsequent emotional gratification in participants with primary psychopathy. Personality and Individual Differences, 51(7), 823-828. https://doi.org/10.1016/j.paid.2011.07.006

McGrath, R. J., Cumming, G. F., Burchard, B. L., Zeoli, S., \& Ellerby, L. (2010). Current practices and emerging trends in sexual abuser management: The Safer Society 2009 North American survey. Brandon, VT, USA: Safer Society Foundation.

Mokros, A., Schilling, F., Eher, R., \& Nitschke, J. (2012). The Severe Sexual Sadism Scale: Crossvalidation and scale properties. Psychological Assessment, 24(3), 764-769. https://doi.org/10.1037/a0026419

Mokros, A., Schilling, F., Weiss, K., Nitschke, J., \& Eher, R. (2014). Sadism in sexual offenders: Evidence for dimensionality. Psychological Assessment, 26(1), 138-147. https://doi.org/10.1037/a0034861

Pinker, S. (2012). The better angels of our nature: Why violence has declined. New York, NY, USA: Penguin.

Polaschek, D. L. L., \& Ward, T. (2002). The implicit theories of potential rapists: What our questionnaires tell us. Aggression and Violent Behavior, 7(4), 385-406. https://doi.org/10.1016/S1359-1789(01)00063-5

Quinsey, V. L. (1986). Men who have sex with children. In D. N. Weisstub (Ed.), Law and mental health: International perspectives (Vol. 2, pp. 140-172). New York, NY, USA: Pergamon.

Roberts, W., \& Strayer, J. (1996). Empathy, emotional expressiveness, and prosocial behavior. Child Development, 67(2), 449-470. https://doi.org/10.2307/1131826 
Rogers, C. R. (1957). The necessary and sufficient conditions of therapeutic personality change. Journal of Consulting Psychology, 21(2), 95-103. https://doi.org/10.1037/h0045357

Seip, E. C., van Dijk, W. W., \& Rotteveel, M. (2009). On hotheads and dirty harries: The primacy of anger in altruistic punishment. Annals of the New York Academy of Sciences, 1167, 190-196. https://doi.org/10.1111/j.1749-6632.2009.04503.x

Seto, M. C. (2019). The motivation-facilitation model of sexual offending. Sexual Abuse, 31(1), 3-24. https://doi.org/10.1177/1079063217720919

Vachon, D. D., Lynam, D. R., \& Johnson, J. A. (2014). The (non)relation between empathy and aggression: Surprising results from a meta-analysis. Psychological Bulletin, 140(3), 751-773. https://doi.org/10.1037/a0035236

Wheeler, S., Book, A., \& Costello, K. (2009). Psychopathic traits and perceptions of victim vulnerability. Criminal fustice and Behavior, 36(6), 635-648.

https://doi.org/10.1177/0093854809333958

World Health Organization. (2019). ICD-11 for Mortality and Morbidity Statistics: 6D33 Coercive sexual sadism disorder. Retrieved from http://id.who.int/icd/entity/1890228613

Young, A. (2012a). Empathic cruelty and the origins of the social brain. In S. Choudhury \& J. Slaby (Eds.), Critical neuroscience: A handbook of the social and cultural contexts of neuroscience (pp. 159-176). Chichester, United Kingdom: Blackwell.

Young, A. (2012b). The social brain and the myth of empathy. Science in Context, 25(3), 401-424. https://doi.org/10.1017/S0269889712000129

\section{Appendix}

\section{Vindictive Rape Attitude Questionnaire (VRAQ)}

How much do you agree with the following statements?

\section{Sluts get no respect from me.}

completely disagree somewhat disagree don't know somewhat agree completely agree or unsure

2. Women who play with men's sexual feelings make me angry. completely disagree somewhat disagree don't know somewhat agree completely agree or unsure

3. If a woman does not play fair sexually, she deserves to be punished.

completely disagree somewhat disagree don't know somewhat agree completely agree or unsure

\section{I can tell when women who flirt are not to be trusted.} completely disagree somewhat disagree don't know somewhat agree completely agree or unsure 
5. When women come on to me, I look out for danger.

completely disagree somewhat disagree don't know

somewhat agree completely agree or unsure

6. Women who do not dress decently are not welcome where I am.

completely disagree somewhat disagree $\quad \begin{gathered}\text { don't know } \\ \text { or unsure }\end{gathered} \quad$ somewhat agree $\quad$ completely agree

7. Men who humiliate sluts are doing us all a favour.

completely disagree somewhat disagree don't know somewhat agree completely agree or unsure

8. Women who say "yes" to sex when they do not mean it lose their right to say "no" later.

completely disagree somewhat disagree don't know $\quad$ somewhat agree completely agree
or unsure

9. If a woman is drunk and flirtatious at a party, it is her fault if some guy takes advantage of her. completely disagree somewhat disagree don't know somewhat agree completely agree or unsure

10. If a woman cheats on her husband, I would have no sympathy if she gets raped.

completely disagree somewhat disagree $\begin{gathered}\text { don't know } \\ \text { or unsure }\end{gathered} \quad \begin{gathered}\text { somewhat agree } \\ \text { completely agree }\end{gathered}$

11. If a woman has committed a sexual crime, then it is justice if she gets raped in prison.

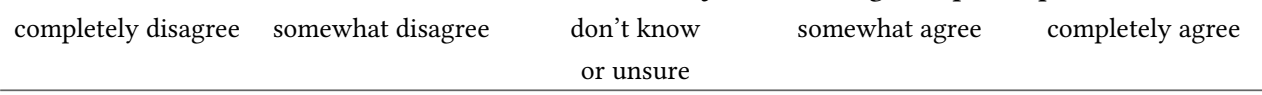

12. I get really angry when I think about women lying and cheating on their partners.

\begin{tabular}{|c|c|c|c|c|}
\hline completely disagree & somewhat disagree & don't know & somewhat agree & completely agree \\
\hline & & or unsure & & \\
\hline
\end{tabular}

13. If a wife does not provide sex for a long time, then eventually the husband has the right to force himself on her.

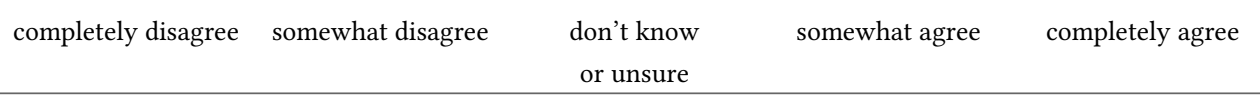

14. When a woman does sexually things that are morally wrong, then it is right that bad sexual things happen to her.
completely disagree somewhat disagree don't know somewhat agree completely agree or unsure

15. A woman who makes a man suffer because of what she does sexually should be made to suffer sexually herself.

\begin{tabular}{|c|c|c|c|c|}
\hline completely disagree & somewhat disagree & $\begin{array}{l}\text { don't know } \\
\text { or unsure }\end{array}$ & somewhat agree & completely agree \\
\hline
\end{tabular}


Sexual Offending: Theory, Research, and Prevention is the official journal of the International Association for the Treatment of Sexual Offenders (IATSO).

\section{(P) leibniz-psychology.org}

PsychOpen GOLD is a publishing service by Leibniz Institute for Psychology Information (ZPID), Germany. 